\title{
Row Spacings and Schedule of Urea Application on Sweet Corn (Zea mays) at MSU-Buug Campus
}

\author{
${ }^{1}$ Junry R. Maato, ${ }^{2}$ Abdani D. Bandera, ${ }^{3}$ Jowie P. Cullamar, ${ }^{4}$ Angelyn M. Montuerto \\ 1,3,4 Department of Plant Science, College of Agriculture, Mindanao State University- Buug Campus \\ ${ }^{2}$ Assistant Professor I, Department of Plant Science, College of Agriculture, Mindanao State University- Buug Campus
}

\begin{abstract}
This study was conducted with an area of $\mathbf{5 4 0}$ square meters excluding canals and was divided into twenty plots. Each plot was measured $3 \mathrm{~m} \times 9 \mathrm{~m}$. The experimental area was laid out following Randomized Complete Block Design (RCBD). The study aimed to determine the effect of different row spacings and schedule of urea application in medium level on the yield of sweet corn. Results of the analysis showed that the average length and average circumference of corn ears in centimeter per plot per treatment both showed no significant difference as affected by different row spacings and schedule of application of urea. Results of the Analysis of Variance (ANOVA) on the average weight and total weight of corn ears in $\mathrm{kg}$ per plot per treatment showed that there was significant difference on the yield of sweet corn using row spacings. However, no significant difference on the schedule of application of urea. Thus, $\mathbf{R}_{\mathbf{2}}$ is recommended in terms of longest husk, biggest circumference of husk, and heavier husk of corn ears. On the other hand, $R_{1}$ is recommended to obtain more husk of corn ears and $R_{5}$ is recommended to obtain heavier husk of corn ears.
\end{abstract}

Keywords:- Sweet Corn, Row Spacings, Schedule of Urea Application, Randomized Complete Block Design (RCBD), Corn Ears.

\section{INTRODUCTION}

Sweet Corn (Zea mays) is observed as one of the important agronomical crops in the Philippines. It is produced by most Filipinos due to its nutritive value. However, the production of this commodity is found costly because it requires high nutrient demand. Hence, to achieve high yield performance, spacings and schedule of fertlizers' application play an important role.

Maize (Zea mays L.) is one of the most important staple food crops in West and Central Africa. The Savanna of West and Central Africa has one of the greatest potential for its major production because of relatively higher incident of solar radiation and lower incident of pest and diseases during the cropping season (Badu-Apraku et al., 2006). In 2008, the world production was 822.7 million tonnes, 53.4 million tonnes for Africa and 7.5 million tonnes for Nigeria (FAO, 2010). Maize production has expanded dramatically in the Northern Guinea Savanna of West Africa where it has replaced traditional cereals and serves as both a food and a cash crop. In West Africa, Manyong et al. (1996) assessed maize as one of the five main crops of the farming systems in 124.7 million hectare or $72 \%$ of West Africa. The Northern Guinea Savanna alone took about $92 \%$ of total area grown to maize in Nigeria. Maize is also widely believed to have the greatest potential among food crops for attaining the technological breakthroughs that will improve food production in the region (Kamara and Sanginga, 2001).

Growing maize at appropriate spacing is one of the bases for higher yield, whereas intra-row spacing at sub optimum is a major constrain to attaining the yield potential of the crop (Alofe et al., 1988). Intra-row spacing for maximum grain yield in maize varies from 20 to $45 \mathrm{~cm}$ (Olson and Sanders, 1988). There is no single recommendation for all environments and all maize types and varieties because optimum spacing for optimum maize yield could vary depending on climatic factors such factors as soil fertility, variety and type, planting date and planting pattern among others (Luis, 2001). The intra-row spacing used by the local farmers for open pollinated extra-early maize was found to be the same as for hybrid, medium and late maturing varieties. This could be a reason for the low yield obtained by farmers. Morphologically, extra-early maize varieties are generally shorter in height (185-190 $\mathrm{cm}$ ), have fewer number of leaves per plant, flowering occurs at about 40 days after sowing (Elemo, 1997). Because of the high nutrient demand by maize, its production requires high inputs of fertilizer. However, because of high cost, unavailability and low levels of soil organic matter, alternative organic sources of nutrients particularly $\mathrm{N}$ needs to be included in maize fertilization. The use of animal manure is needed to ensure an efficient nutrient management in the maize-based cropping systems in the Northern Guinea Savanna. Research conducted in Northern Guinea Savanna and elsewhere had shown great improvement in the yield of crop as a result of improvement in organic matter content of the soil (Boateng et al., 2006). In this study, it aimed to determine the effect of different row spacings and schedule of urea application in medium level on the yield of sweet corn. 


\section{MATERIALS AND METHODS}

Materials used in the study are carabao drawn plow, harrow, bolo, sprayer, meter stick, straw lace, treatment indicators, sign board, shovel, weighing scale, tape measure, cellophanes, record book, ball pen, sacks, and camera. Macho F1 corn variety was used in the study. Variety used can be harvested 75-80 days after planting. The inorganic fertilizers used are: Urea (46-0-0), Muriate of Potash (0-0-60), and Ammonium Phosphate (16-20-0). In this study, Lannate TM 40 SP and Ridomil were used to control insect pests and diseases.

An area of 540 square meters excluding canals was utilized by slashing the existing weeds, then the area was plowed thoroughly using carabao drawn plow. Plowing was done twice. The area was equally divided into 20 plots. Each plot measures 3 meters by 9 meters. Randomized Complete Block Design (RCBD) was used in this study. Random numbers were generated from calculator and were used in the distribution of each treatment to every plot by ranking them from lowest to highest. The area was thoroughly prepared. Two seeds were sown in every hill with a distance of 60-80 centimeters between rows and 20 centimeters between hills. There were 900 plants in $\mathrm{R}_{1}, 840$ plants in $R_{2}, 780$ plants in $R_{3}, 720$ plants in $R_{4}$, and 660 plants in $\mathrm{R}_{5}$ with four plots. Thinning started seven (7) to ten (10) days after planting by removing unhealthy seedlings, leaving only one plant per hill.

A day before planting, Ammonium Phosphate (16-20$0)$ was applied at a rate of 1.38 gram and Muriate of Potash (0-0-60) at a rate of 0.69 gram per hill. After 15 days of planting, Ammonium Phosphate (16-20-0) at a rate of 1.38 grams per hill was applied (first and second side dressing) 24, 26, 28, and 30 days after planting. Medium level of Urea (46-0-0) was applied at a rate of 1.40 gram per hill during $24,26,28$, and 30 days after planting.

Cultivation was done simultaneously in the 14 to 18 days after planting and was repeated 22 to 25 days after planting. Weeds were controlled by uprooting manually with the use of hand. Corn plants were irrigated 0-3 DAS, 13-15 DAS, 30-35 DAS, 45-55 DAS, and 65-80 DAS with sufficient amount of water for the growth of the crop using sprinkler, pail and deeper. A foliar application of $0.864 \mathrm{~L}$ of Lannate TM 40SP was done to plants 30 days after planting to control earworms, cutworms, brown plant hoppers and corn borers on the field. For the prevention of downy mildew development on the crop, the seeds were mixed with fungicide before planting using Ridomil. Harvesting was done 75-80 days after planting. It was done manually by removing the ears of corn from the stalk. Corn ears were harvested and labeled in separate containers according to plot to avoid mixing and mispresentation of data.

There were 68 samples in $R_{1}, 63$ in $R_{2}, 59$ in $R_{3}, 54$ in $\mathrm{R}_{4}$, and 50 in $\mathrm{R}_{5}$. Choosing of plant samples was done by drawing of lots in every plot. Collection of data was done during harvesting by picking first the corn ear from the sample plant before harvesting the entire plants in every plot. The data collected were the following: (1) Average length of corn ears in centimeter per plant per treatment, (2) average circumference of corn ears in centimeter per plant per treatment, (3) average weight of corn ears in grams per plot per treatment, (4) total number of corn ears per plot per treatment, and (5) total weight of corn ears in kilograms per plot per treatment.

The length of each corn ear from the sample plants in every plot was measured using a ruler and then added. The result was divided by the total number of sample to get the average length. The circumference of each corn ear from the sample plants in every plot was measured using tape measure and was added. The result was divided by total number of sample to get the average circumference. The weight of each corn ear from the sample plants in every plot was taken using a weighing scale and was added. The result was divided by the total number of sample to get the average weight. All corn ears from each plot were collected and were counted to get the total number of corn ears per plot. In addition, All corn ears from each plot were collected and were weighed using a weighing scale to get the total weight of corn ears per plot per treatment.

Analysis of Variance (ANOVA) was used in two way classification without inter-action to determine if there is a significant difference in the yield performance of sweet corn using different row spacings and schedule of application of urea in medium level. Scheffe method was used to determine if there is significant difference based on the ANOVA table to observe which of the different row spacings and schedule of application of Urea will give the highest yield of sweet corn. Below are the treatments used in this study: 
ISSN No:-2456-2165

\begin{tabular}{|c|c|c|c|}
\hline \multirow[t]{2}{*}{ Treatments } & \multirow[t]{2}{*}{ Variables' Combinations } & \multicolumn{2}{|c|}{ Description } \\
\hline & & Row Spacings (R) & Schedule of Application (F) \\
\hline$\overline{\mathbf{T}_{1}}$ & $\overline{\mathrm{R}_{1} \mathrm{~F}_{1}}$ & $60 \mathrm{~cm}$ between rows & 24 Days after planting \\
\hline $\mathbf{T}_{2}$ & $\mathrm{R}_{1} \mathrm{~F}_{2}$ & $60 \mathrm{~cm}$ between rows & 26 Days after planting \\
\hline $\mathbf{T}_{3}$ & $\mathrm{R}_{1} \mathrm{~F}_{3}$ & $60 \mathrm{~cm}$ between rows & 28 Days after planting \\
\hline $\mathbf{T}_{4}$ & $\mathrm{R}_{1} \mathrm{~F}_{4}$ & $60 \mathrm{~cm}$ between rows & 30 Days after planting \\
\hline $\mathbf{T}_{5}$ & $\mathrm{R}_{2} \mathrm{~F}_{1}$ & $65 \mathrm{~cm}$ between rows & 24 Days after planting \\
\hline $\mathbf{T}_{6}$ & $\mathrm{R}_{2} \mathrm{~F}_{2}$ & $65 \mathrm{~cm}$ between rows & 26 Days after planting \\
\hline $\mathbf{T}_{7}$ & $\mathrm{R}_{2} \mathrm{~F}_{3}$ & $65 \mathrm{~cm}$ between rows & 28 Days after planting \\
\hline $\mathbf{T}_{8}$ & $\mathrm{R}_{2} \mathrm{~F}_{4}$ & $65 \mathrm{~cm}$ between rows & 30 Days after planting \\
\hline $\mathbf{T}_{9}$ & $\mathrm{R}_{3} \mathrm{~F}_{1}$ & $70 \mathrm{~cm}$ between rows & 24 Days after planting \\
\hline $\mathbf{T}_{10}$ & $\mathrm{R}_{3} \mathrm{~F}_{2}$ & $70 \mathrm{~cm}$ between rows & 26 Days after planting \\
\hline $\mathbf{T}_{11}$ & $\mathrm{R}_{3} \mathrm{~F}_{3}$ & $70 \mathrm{~cm}$ between rows & 28 Days after planting \\
\hline $\mathbf{T}_{22}$ & $\mathrm{R}_{3} \mathrm{~F}_{4}$ & $70 \mathrm{~cm}$ between rows & 30 Days after planting \\
\hline $\mathbf{T}_{13}$ & $\mathrm{R}_{4} \mathrm{~F}_{1}$ & $75 \mathrm{~cm}$ between rows & 24 Days after planting \\
\hline $\mathbf{T}_{14}$ & $\mathrm{R}_{4} \mathrm{~F}_{2}$ & $75 \mathrm{~cm}$ between rows & 26 Days after planting \\
\hline $\mathbf{T}_{15}$ & $\mathrm{R}_{4} \mathrm{~F}_{3}$ & $75 \mathrm{~cm}$ between rows & 28 Days after planting \\
\hline $\mathbf{T}_{16}$ & $\mathrm{R}_{4} \mathrm{~F}_{4}$ & $75 \mathrm{~cm}$ between rows & 30 Days after planting \\
\hline $\mathbf{T}_{17}$ & $\mathrm{R}_{5} \mathrm{~F}_{1}$ & $80 \mathrm{~cm}$ between rows & 24 Days after planting \\
\hline $\mathbf{T}_{18}$ & $\mathrm{R}_{5} \mathrm{~F}_{2}$ & $80 \mathrm{~cm}$ between rows & 26 Days after planting \\
\hline $\mathbf{T}_{19}$ & $\mathrm{R}_{5} \mathrm{~F}_{3}$ & $80 \mathrm{~cm}$ between rows & 28 Days after planting \\
\hline $\mathbf{T}_{20}$ & $\mathrm{R}_{5} \mathrm{~F}_{4}$ & $80 \mathrm{~cm}$ between rows & 30 Days after planting \\
\hline
\end{tabular}

Treatments (T); Row Spacings $(R) ;$ Schedule of Application $(F)$

\section{RESULTS AND DISCUSSION}

\section{Average Length of Corn Ears ( in cm)}

Table 2 presents the average length of corn ears in centimeter per plot per treatment. It shows that in row spacing, $\mathrm{R}_{5}$ obtained the longest average length of $(29.46$ $\mathrm{cm})$, followed by $\mathrm{R}_{2}$ with $(28.56 \mathrm{~cm}), \mathrm{R}_{4}$ obtained $(28.46$ $\mathrm{cm}), \mathrm{R}_{3}$ with $(27.83 \mathrm{~cm})$ and the shortest average length is in $\mathrm{R}_{1}$ with $(27.39) \mathrm{cm}$. The schedule of urea application in medium level treatment shows that $\mathrm{F}_{3}$ obtained the longest average length of $(28.43 \mathrm{~cm})$, followed by $F_{1}$ with $(28.36$ $\mathrm{cm}$ ) and the shortest average length are $F_{2}$ and $F_{4}$ with $(28.29 \mathrm{~cm})$.

\begin{tabular}{|l|l|l|l|l|l|l|l|}
\hline \multirow{2}{*}{$\begin{array}{c}\text { Urea } \\
\text { Fertilizer }\end{array}$} & \multicolumn{5}{|c|}{ Row Spacing } & \multirow{2}{*}{ TOTAL } & \multirow{2}{*}{ MEAN } \\
\cline { 2 - 7 } & $\mathbf{R}_{\mathbf{1}}$ & $\mathbf{R}_{\mathbf{2}}$ & \multicolumn{1}{|c|}{$\mathbf{R}_{\mathbf{3}}$} & $\mathbf{R}_{\mathbf{4}}$ & $\mathbf{R}_{\mathbf{5}}$ & & \\
\hline $\mathbf{F}_{\mathbf{1}}$ & 27.5 & 28.42 & 29.3 & 27.48 & 29.1 & 141.8 & 28.36 \\
\hline $\mathbf{F}_{\mathbf{2}}$ & 27.33 & 26.47 & 27.64 & 29.98 & 30.04 & 141.46 & 28.29 \\
\hline $\mathbf{F}_{\mathbf{3}}$ & 28.14 & 29.22 & 27.22 & 28.25 & 29.32 & 142.15 & 28.43 \\
\hline $\mathbf{F}_{\mathbf{4}}$ & 26.6 & 30.14 & 27.18 & 28.16 & 29.38 & 141.46 & 28.29 \\
\hline TOTAL & 109.57 & 114.25 & 111.34 & 113.87 & 117.84 & $\mathbf{5 6 6 . 8 7}$ & \\
\hline MEAN & 27.39 & 28.56 & 27.83 & 28.46 & 29.46 & & $\mathbf{2 8 . 3 4}$ \\
\hline
\end{tabular}

Table 2:- Average Length of Corn Ears in Centimeter per Plot per Treatment.

The result of statistical analysis revealed that the computed "f" $(0.02)$ is lesser than the tabulated " $\mathrm{f}_{1}$ " at $5 \%$ (3.49) and at $1 \%$ (5.95). Therefore, the null hypothesis is accepted in both $5 \%$ and $1 \%$, levels of significance in different schedule of Urea application in medium level. In addition, based on statistical analysis the result revealed that the computed " $f_{2}$ " $(1.93)$ is lesser than the tabulated " $\mathrm{f}_{2}$ " at 5\% (3.26) and at 1\% (5.49). Therefore, the null hypothesis is accepted in both $5 \%$ and $1 \%$ levels of significance in different row spacings. This means that there is no significant difference at $5 \%$ and $1 \%$ on the average length of corn ears per plot in both different row spacings and times of Urea application in medium level (See Table 7).

\section{$>$ Average Circumference of Corn Ears (in cm)}

Table 3 presents the average circumference of corn ears in centimeter per plot per treatment. It shows that in row spacing, $\mathrm{R}_{5}$ gained the biggest average circumference of $(19.75 \mathrm{~cm})$ followed by $\mathrm{R}_{4}$ with $(19.28 \mathrm{~cm}), \mathrm{R}_{2}$ with $(19.25 \mathrm{~cm}), \mathrm{R}_{3}$ with $(19.14 \mathrm{~cm})$ and $\mathrm{R}_{5}$ obtained the smallest circumference of corn ears with an average of $(18.90 \mathrm{~cm})$. The schedule of urea application in medium level treatment shows that $\mathrm{F}_{3}$ obtained the biggest average circumference of $(19.44 \mathrm{~cm})$, followed by $F_{1}$ with $(19.36 \mathrm{~cm}), F_{4}$ with $(19.17$ $\mathrm{cm})$ and $\mathrm{F}_{2}$ obtained the smallest average circumference with $(19.09 \mathrm{~cm})$.

\begin{tabular}{|c|c|c|c|c|c|c|c|}
\hline \multirow{2}{*}{$\begin{array}{c}\text { Urea } \\
\text { Fertilizer }\end{array}$} & \multicolumn{5}{|c|}{ Row Spacing } & \multirow{2}{*}{ TOTAL } & \multirow{2}{*}{ MEAN } \\
\cline { 2 - 6 } & $\mathbf{R}_{\mathbf{1}}$ & $\mathbf{R}_{\mathbf{2}}$ & $\mathbf{R}_{\mathbf{3}}$ & $\mathbf{R}_{\mathbf{4}}$ & $\mathbf{R}_{\mathbf{5}}$ & & \\
\hline $\mathrm{F}_{\mathbf{1}}$ & 19.67 & 19.28 & 19.08 & 18.83 & 19.96 & 96.82 & 19.36 \\
\hline $\mathrm{F}_{2}$ & 18.58 & 18.36 & 19.25 & 19.92 & 19.36 & 95.47 & 19.09 \\
\hline $\mathrm{F}_{3}$ & 18.72 & 19.39 & 19.35 & 19.46 & 20.28 & 97.2 & 19.44 \\
\hline $\mathrm{F}_{4}$ & 18.64 & 19.98 & 18.91 & 18.91 & 19.42 & 95.86 & 19.17 \\
\hline TOTAL & 75.61 & 77.01 & 76.59 & 77.12 & 79.02 & $\mathbf{3 8 5 . 3 5}$ & \\
\hline MEAN & 18.90 & 19.25 & 19.14 & 19.28 & 19.75 & & $\mathbf{1 9 . 2 6}$ \\
\hline
\end{tabular}

Table 3:- Average Circumference of Corn Ears in Centimeter per Plant per Plot per Treatment. 
ISSN No:-2456-2165

Result of the statistical analysis revealed that the computed " $\mathrm{f}$ " $(0.48)$ is lesser than the tabulated " $\mathrm{F}_{1}$ " at $5 \%$ (3.49) and at $1 \%(5.95)$. Therefore, the null hypothesis is accepted in both $5 \%$ and $1 \%$ levels of significance in different schedule of Urea application in medium levels. In addition, based on statistical analysis the result revealed that the computed " $f_{2}$ " $(1.43)$ is lesser than the tabulated " $\mathrm{f}_{2}$ " at $5 \%$ (3.26) and at $1 \%(5.49)$. Therefore, the null hypothesis is accepted in both $5 \%$ and $1 \%$ levels of significance in different row spacings. This means that there is no significant difference at $5 \%$ and $1 \%$ on the average circumference of corn ears per plot in both different row spacings and schedule of Urea application in medium level (See Table 8).

\section{$>$ Average Weight of Corn Ears (in Grams)}

Table 4 presents the average weight of corn ears in centimeter per plot per treatment. It shows that in row spacing, $\mathrm{R}_{5}$ acquired the heaviest average weight of (352.39 g) followed by $\mathrm{R}_{4}$ with $(328.83 \mathrm{~g}), \mathrm{R}_{2}$ with $(311.26 \mathrm{~g}), \mathrm{R}_{3}$ with $(299.52 \mathrm{~g})$ and $\mathrm{R}_{1}$ obtained the least average weight of corn ears with (286.96 g). In addition, the table shows that $\mathrm{F}_{3}$ obtained the heaviest average weight of $(322.81 \mathrm{~g})$, followed by $F_{1}$ with $(317.92 \mathrm{~g}), \mathrm{F}_{4}$ with $(315.84 \mathrm{~g})$ and $\mathrm{F}_{2}$ gained the lightest average weight with $(306.60 \mathrm{~g})$.

\begin{tabular}{|c|c|c|c|c|c|c|c|}
\hline \multirow{2}{*}{\begin{tabular}{|c|} 
Urea \\
Fertilizer \\
\end{tabular}} & \multicolumn{5}{|c|}{ Row Spacing } & \multirow{2}{*}{ TOTAL } & \multirow{2}{*}{ MEAN } \\
\hline & $\mathrm{R}_{1}$ & $\mathrm{R}_{2}$ & $\mathrm{R}_{3}$ & $\mathrm{R}_{4}$ & $\mathrm{R}_{5}$ & & \\
\hline$F_{1}$ & 331.17 & 303.01 & 301.64 & 300.61 & 353.18 & 1589.61 & 317.92 \\
\hline $\mathrm{F}_{2}$ & 265.61 & 264.55 & 321.96 & 344.92 & 335.98 & 1533.02 & 306.60 \\
\hline $\mathrm{F}_{3}$ & 282.73 & 326.28 & 288.08 & 332.74 & 384.22 & 1614.05 & 322.81 \\
\hline $\mathrm{F}_{4}$ & 268.35 & 351.22 & 286.4 & 337.05 & 336.2 & 1579.22 & 315.84 \\
\hline TOTAL & 1147.86 & 1245.06 & 1198.08 & 1315.32 & 1409.58 & 6315.9 & \\
\hline MEAN & 286.96 & 311.26 & 299.52 & 328.83 & 352.39 & & 315.79 \\
\hline
\end{tabular}

Table 4:- Average Weight of Corn Ears in Grams per Plot per Treatment.

The result of the statistical analysis revealed that the computed " $\mathrm{f}$ " $(0.29)$ is lesser than the tabulated " $\mathrm{f}_{1}$ " at $5 \%$ (3.49) and at $1 \%$ (5.95). Therefore, the null hypothesis is accepted in both $5 \%$ and $1 \%$ levels of significance in different schedule of Urea application in medium level. In addition, based on statistical analysis the result revealed that the computed " $f_{2}$ " (3.27) is greater than the tabulated " $f_{2}$ " at $5 \%(3.26)$ but lesser than at $1 \%(5.49)$. Therefore, the alternative hypothesis is accepted in 5\% and null hypothesis is accepted in $1 \%$ on the average weight of corn ears in different row spacings (See Table 9).

\section{Total Number of Corn Ears (in Centimeter)}

Table 5 reveals the total number of corn ears per plot per treatment. The table below shows that in row spacing, $\mathrm{R}_{1}$ gained the highest total number of corn ears of (255.75) followed by $\mathrm{R}_{2}$ with (226.5), $\mathrm{R}_{3}$ with (204.75), $\mathrm{R}_{4}$ with (199) and $R_{5}$ obtained the least number of corn ears with total number of (185). Moreover, the table shows that $F_{2}$ acquired the highest total number of (216.4), followed by $F_{4}$ with (215.4), $F_{1}$ with (213.3) and $F_{3}$ obtained the least number of corn ears having a total number of (212).

\begin{tabular}{|c|c|c|c|c|c|c|c|}
\hline \multirow{2}{*}{$\begin{array}{c}\text { Urea } \\
\text { Fertilizer }\end{array}$} & \multicolumn{5}{|c|}{ Row Spacing } & \multirow{2}{*}{ TOTAL } & \multirow{2}{*}{ MEAN } \\
\cline { 2 - 8 } & $\mathrm{R}_{1}$ & $\mathrm{R}_{2}$ & $\mathrm{R}_{3}$ & $\mathrm{R}_{4}$ & $\mathrm{R}_{5}$ & & \\
\hline $\mathbf{F}_{\mathbf{1}}$ & 268 & 225 & 201 & 200 & 171 & 1065 & 213 \\
\hline $\mathbf{F}_{\mathbf{2}}$ & 248 & 238 & 213 & 198 & 185 & 1082 & 216.4 \\
\hline $\mathbf{F}_{3}$ & 251 & 225 & 201 & 195 & 188 & 1060 & 212 \\
\hline $\mathbf{F}_{\mathbf{4}}$ & 256 & 218 & 204 & 203 & 196 & 1077 & 215.4 \\
\hline TOTAL & 1023 & 906 & 819 & 796 & 740 & $\mathbf{4 2 8 4}$ & \\
\hline MEAN & 255.75 & 226.5 & 204.75 & 199 & 185 & & $\mathbf{2 1 4 . 2}$ \\
\hline
\end{tabular}

Table 5:- Total Number of Corn Ears in Centimeter per Plot per Treatment

Result of the statistical analysis revealed that the computed " $\mathrm{f}$ " $(0.30)$ is lesser than the tabulated " $\mathrm{f}_{1}$ " at $5 \%$ (3.49) and at $1 \%(5.95)$. Therefore, the null hypothesis is accepted in both $5 \%$ and $1 \%$ levels of significance in different schedule of Urea application in medium level. In addition, based on statistical analysis the result revealed that the computed " $\mathrm{f}$ " $(43.81)$ is greater than the tabulated " $f_{2}$ " at $5 \%(3.26)$ and at $1 \%(5.49)$. Therefore, the alternative hypothesis is accepted in both $5 \%$ and $1 \%$ levels of significance in different row spacings (See Table 10).

\section{Total Weight of Corn Ears (in Kilograms)}

Table 6 presents the total weight of corn ears in kilogram per plot per treatment. The table shows that in row spacing treatment, $\mathrm{R}_{2}$ gained the heaviest total weight $(45.12 \mathrm{~kg})$ of corn ears followed by $\mathrm{R}_{3}(42.12 \mathrm{~kg}), \mathrm{R}_{1}(41.62$ $\mathrm{kg}$ ), and $\mathrm{R}_{5}$ with $(38.87 \mathrm{~kg}) . \mathrm{R}_{4}$ gained the lightest total weight of corn ears in kilogram per plot per treatment with a total of $(33.87 \mathrm{~kg})$. In addition, the table shows that $F_{1}$ acquired the heaviest total weight of $(210.5 \mathrm{~kg})$, followed by $F_{3}(208.5 \mathrm{~kg}), F_{2}$ with $(196 \mathrm{~kg})$ and $F_{4}$ obtained the lightest total weight of corn ears in kilogram per plot per treatment having a total weight of $(191.5 \mathrm{~kg})$.

\begin{tabular}{|c|c|c|c|c|c|c|c|}
\hline \multirow{2}{*}{$\begin{array}{c}\text { Urea } \\
\text { Fertilizer }\end{array}$} & \multicolumn{5}{|c|}{ Row Spacing } & \multirow{2}{*}{ TOTAL } & \multirow{2}{*}{ MEAN } \\
\hline & $R_{1}$ & $\mathrm{R}_{2}$ & $\mathrm{R}_{3}$ & $\mathrm{R}_{4}$ & $\mathrm{R}_{5}$ & & \\
\hline $\mathrm{F}_{1}$ & 48.5 & 40.5 & 48.5 & 33 & 40 & 210.5 & 42.1 \\
\hline $\mathrm{F}_{2}$ & 38 & 45 & 42 & 31 & 40 & 196 & 39.2 \\
\hline $\mathrm{F}_{3}$ & 40 & 46 & 41 & 38.5 & 43 & 208.5 & 41.7 \\
\hline $\mathrm{F}_{4}$ & 40 & 49 & 37 & 33 & 32.5 & 191.5 & 38.3 \\
\hline TOTAL & 166.5 & 180.5 & 168.5 & 135.5 & 155.5 & 806.5 & \\
\hline MEAN & 41.62 & 45.12 & 42.12 & 33.87 & 38.87 & & 40.32 \\
\hline
\end{tabular}

Table 6:- Total Weight of Corn Ears in Kilograms per Plot per Treatment

The result of the statistical analysis revealed that the computed " $\mathrm{f}$ " $(0.99)$ is lesser than the tabulated " $\mathrm{f}_{1}$ " at $5 \%$ (3.49) and at $1 \%$ (5.95). Therefore, the null hypothesis is accepted in both $5 \%$ and $1 \%$ levels of significance in different schedule of Urea application in medium level. In addition, based on statistical analysis the results revealed that the computed " $f_{2}$ " (4.09) is greater than the tabulated " $f_{2}$ " at 5\% (3.26) but lesser than at 1\% (5.49). Therefore, the alternative hypothesis is accepted in $5 \%$ and null hypothesis is accepted in $1 \%$ levels of significance in different row spacings (See Table 11). 


\section{CONCLUSION}

Based on the result of the study, the following conclusions were drawn:

$>$ There is no significant difference on the average length of corn ears in centimeter per plot per treatment;

$>$ There is no significant difference on the average circumference of corn ears in centimeter per plot per treatment;

There is a significant difference on the average weight of corn ears in gram per plot per treatment;

There is a significant difference on the total number of corn ears per plot per treatment; and

There is a significant difference on the total weight of corn ears per plot per treatment.

\section{RECOMMENDATIONS}

Based on the previous findings and conclusions, the following are highly recommended: To obtain longest husk corn ears and biggest circumference husk corn ears, any of the combined treatments are recommended. However, to achieve heavier husk corn ears and to obtain more husk corn ears, $\mathrm{R}_{2}$ and $\mathrm{R}_{1}$ are recommended respectively.

\section{REFERENCES}

[1]. Alofe, C.O., Kim, S.K., Efron, Y., Fajemisin, J.M., Khadr, F.H. and Kang, B.T (1988). Effect of nitrogen and plant density on grain performance of hybrid maize in the forest and derived savanna zone of Nigeria. National Conference on maize, Ile-Ife Abstract 17pp
[2]. Badu-Apraku, B., Menkir, A., Fakorede, M.A.B., Fonten Lum, A. and K., Obeng-Antwi (2006) Multivariate analyses of the genetic diversity of fortyseven Striga resistant tropical early maturing maize inbred lines. Maydica 51: 551-559

[3]. Boateng, S. A, Zickermann, J. and Kornahrens, M. (2006). Poultry Manure Effect on Growth and Yield of maize. Crop Science Journal, 8 (3): 273-282

[4]. Elemo, K.A (1997). Extra-early maize varieties as affected by the rate and time of $\mathrm{N}$ fertilization. Production of reginal maize workshop IITA-Cotonou, Benin Republic: 419-425.

[5]. FAO (2010). Food and Agriculture Organisation Statistics, FAOSTAT. www.fao.org/faostat

[6]. Kamara, A.Y. and Sanginga, N (2001). Balance nutrient management for intensified maize-based systems in the Northern Guinea Savanna of West Africa. In: Proceeding of the National Quality Protein Maize Production Workshop 4th - 5th September 2001 at Institute for Agricultural Research Comperence Hall A.B.U., Zaria pp 17-24.

[7]. Luis, S (2001). Understanding plant density effects on maize growth and development: An important issue to maximize grain yield. Ciencia Rural 3(1): 1-17

[8]. Manyong, V.M., Smith, J., Webe, G.K., Jagtap, S.S and Oyewole, B (1996). Macro-characterization of agricultural systems in West Africa: An Over view Research and Crop Management Research Monograph No. 21. International Institute of Tropical Agriculture (IITA), Ibadan, Nigeria.

[9]. Olson, R.A and D.H. Sanders (1988). Crop production in corn and corn improvement Madison W.I. U.S.A: 686

\section{APPENDICES}

\begin{tabular}{|l|c|c|c|c|c|c|}
\hline Source of Variation & $\begin{array}{c}\text { Sum of } \\
\text { Square }\end{array}$ & $\begin{array}{c}\text { Degree of } \\
\text { Freedom }\end{array}$ & $\begin{array}{c}\text { Mean of } \\
\text { Square }\end{array}$ & $\begin{array}{c}\text { Computed } \\
\boldsymbol{f}\end{array}$ & & \multicolumn{2}{|c|}{ Tabulated $\boldsymbol{f}$} \\
\cline { 6 - 8 } & & & $\mathbf{5} \%$ & $\mathbf{1} \%$ \\
\hline $\begin{array}{l}\text { Different Times of Urea } \\
\text { Application in Medium }\end{array}$ & 0.07 & 3.00 & 0.02 & 0.02 & 3.49 & 5.95 \\
\hline Different Row Spacings & 9.89 & 4.00 & 2.47 & 1.93 & 3.26 & 5.49 \\
\hline Error & 15.34 & 12.00 & 1.28 & & & \\
\hline Total & 25.30 & 19.00 & & & & \\
\hline
\end{tabular}

Table 7:- ANOVA for the Average Length of Corn Ears in Centimeter per Plot per Treatment

\begin{tabular}{|l|l|l|l|l|l|l|}
\hline Source of Variation & $\begin{array}{l}\text { Sum of } \\
\text { Square }\end{array}$ & $\begin{array}{l}\text { Degree of } \\
\text { Freedom }\end{array}$ & $\begin{array}{l}\text { Mean of } \\
\text { Square }\end{array}$ & $\begin{array}{l}\text { Computed } \\
\boldsymbol{f}\end{array}$ & \multicolumn{2}{|l|}{ Tabulated $\boldsymbol{f}$} \\
\cline { 6 - 8 } & 0.39 & 3.00 & 0.13 & 0.48 & 3.49 & $\mathbf{5} \%$ \\
\hline $\begin{array}{l}\text { Different Times of } \\
\text { Urea Application }\end{array}$ & 0.95 & & & & \\
\hline $\begin{array}{l}\text { Different Row } \\
\text { Spacings }\end{array}$ & 1.54 & 4.00 & 0.39 & 1.43 & 3.26 & 5.49 \\
\hline Error & 3.23 & 12.00 & 0.27 & & & \\
\hline Total & 5.16 & 19.00 & & & & \\
\hline
\end{tabular}

Table 8:- ANOVA for the Average Circumference of Corn Ears in Centimeter per Plot per Treatment 


\begin{tabular}{|l|c|c|c|c|c|c|}
\hline Source of Variation & $\begin{array}{c}\text { Sum of } \\
\text { Square }\end{array}$ & $\begin{array}{c}\text { Degree of } \\
\text { Freedom }\end{array}$ & $\begin{array}{c}\text { Mean of } \\
\text { Square }\end{array}$ & $\begin{array}{c}\text { Computed } \\
\boldsymbol{f}\end{array}$ & \multicolumn{2}{|c|}{ Tabulated $\boldsymbol{f}$} \\
\cline { 5 - 7 } & & $\mathbf{5} \%$ & $\mathbf{1} \%$ \\
\hline Different Times of Urea & 691.06 & 3.00 & 230.35 & 0.29 & 3.49 & 5.95 \\
\hline Different Row Spacings & $10,504.15$ & 4.00 & $2,626.04$ & 3.27 & 3.26 & 5.49 \\
\hline Error & $9,650.15$ & 12.00 & 804.18 & & & \\
\hline Total & $20,845.35$ & 19.00 & & & & \\
\hline
\end{tabular}

Table 9:- ANOVA for the Average Weight of Corn Ears in Gram per Plot per Treatment

\begin{tabular}{|l|l|l|l|l|l|l|}
\hline Source of Variation & $\begin{array}{l}\text { Sum of } \\
\text { Square }\end{array}$ & $\begin{array}{l}\text { Degree of } \\
\text { Freedom }\end{array}$ & $\begin{array}{l}\text { Mean of } \\
\text { Square }\end{array}$ & $\begin{array}{l}\text { Computed } \\
f\end{array}$ & & \multicolumn{2}{|l|}{ Tabulated $\boldsymbol{f}$} \\
\cline { 3 - 7 } & & & & $\mathbf{5} \%$ & $\mathbf{1 \%}$ \\
\hline $\begin{array}{l}\text { Different Times of Urea } \\
\text { Application in Medium } \\
\text { Level }\end{array}$ & 62.80 & 3.00 & 20.93 & 0.30 & 3.49 & 5.95 \\
\hline Different Row Spacings & $12,202.70$ & 4.00 & & & & \\
\hline Error & 835.70 & 12.00 & 69.650 .67 & 43.81 & 3.26 & 5.49 \\
\hline Total & $13,101.20$ & 19.00 & & & & \\
\hline
\end{tabular}

Table 10:- ANOVA for the Total Number of Corn Ears in Gram per Plot per Treatment.

\begin{tabular}{|c|c|c|c|c|c|c|}
\hline \multirow[t]{2}{*}{ Source of Variation } & \multirow{2}{*}{$\begin{array}{l}\text { Sum of } \\
\text { Square }\end{array}$} & \multirow{2}{*}{$\begin{array}{l}\text { Degree of } \\
\text { Freedom }\end{array}$} & \multirow{2}{*}{$\begin{array}{l}\text { Mean of } \\
\text { Square }\end{array}$} & \multirow{2}{*}{$\begin{array}{l}\text { Computed } \\
f\end{array}$} & \multicolumn{2}{|c|}{ Tabulated $f$} \\
\hline & & & & & $\mathbf{5} \%$ & $1 \%$ \\
\hline $\begin{array}{l}\text { Different Times of Urea } \\
\text { Application in Medium } \\
\text { Level }\end{array}$ & 52.04 & 3.00 & 17.35 & 0.99 & 3.49 & 5.95 \\
\hline Different Row Spacings & 286.70 & 4.00 & 71.68 & 4.09 & 3.26 & 5.49 \\
\hline Error & 210.40 & 12.00 & 17.53 & & & \\
\hline Total & 549.14 & 19.00 & & & & \\
\hline
\end{tabular}

Table 11:- ANOVA for the Total Weight of Corn Ears in Kilogram per Plot per Treatment. 